\title{
Pandemics and the politics of difference: rewriting the history of internationalism through nineteenth-century cholera $^{\dagger}$
}

\author{
Valeska Huber \\ Department of History, Freie Universität Berlin, Koserstrasse 20, 14195 Berlin, Germany \\ Corresponding author. E-mail: valeska.huber@fu-berlin.de
}

\begin{abstract}
This article revisits the origins of internationalism in the field of health and shows how the cholera epidemics of the nineteenth century, much like the current coronavirus crisis, brought global differences such as social inequalities, political hierarchies, and scientific conflicts to the fore. Beyond drawing parallels between the cholera epidemics and the current crisis, the article argues for combining imperial and social histories in order to write richer and more grounded histories of internationalism. It explores this historiographical and methodological challenge by analysing the boardrooms of the international sanitary conferences, Middle Eastern quarantine stations catering for Mecca pilgrims, and ocean steamships aiming to move without delay during a worldwide health crisis.
\end{abstract}

Keywords: cholera; contagion; empire; inequality; internationalism; transport and communication

\section{Introduction}

Cholera is a subject which concerns most immediately, not only our personal and national interests, but, it may be said without exaggeration, it concerns the whole human race. ${ }^{1}$

The nineteenth-century cholera epidemics reaching Asia, Europe, Africa, and the Americas in different eruptions between the 1820s and the 1890s coincided with the bacteriological revolution and the popularization of knowledge about the vibrio cholerae microbe causing the disease. ${ }^{2}$ At the same time, cholera became linked to another 'revolution': in the last third of the nineteenth century, new means of transport and communication such as the steamship and the railway

\footnotetext{
${ }^{\dagger}$ For perceptive comments and inspiring discussions, thanks go to the members of the Emmy Noether Research Group 'Reaching the People: Communication and Global Orders in the Twentieth Century' (Lea Börgerding, Joel Hide, Nida Kazmi, and Sophie-Jung Kim), as well as to Sebastian Conrad, Michael Christopher Low, and Heidi Tworek for their helpful suggestions.

${ }^{1}$ Thomas Whiteside Hime, 'Introduction', in Max von Pettenkofer, Cholera: How to Prevent and Resist It, trans. Thomas Whiteside Hime (London: Baillière, Tindall, and Cox, 1875), 5-6.

${ }^{2}$ Andrew Cunningham and Perry Williams, eds., The Laboratory Revolution in Medicine (Cambridge: Cambridge University Press, 1992); Michael Worboys, 'Was There a Bacteriological Revolution in Late Nineteenth-Century Medicine?', Studies in History and Philosophy of Science 38, no. 1 (2007): 20-42.

(C) The Author(s), 2020. Published by Cambridge University Press. This is an Open Access article, distributed under the terms of the Creative Commons Attribution licence (http://creativecommons.org/licenses/by/4.0/), which permits unrestricted re-use, distribution, and reproduction in any medium, provided the original work is properly cited.
} 
accelerated global traffic. ${ }^{3}$ The idea that something invisible to the naked eye could spread around the world and was more potent than humans, states, and empires shook the sense of security of Western powers and exposed their vulnerability. Then as now, a worldwide pandemic created paradoxes, exposing the tensions between openness and closure of worldwide communication. Even as cholera threatened global projects of free trade and imperial expansion, it led to the first international sanitary conferences and attempts to foster cooperation over disease control.

The conundrum of whether and how to build effective barriers against a microscopic invader sounds eerily familiar in 2020. Late nineteenth-century debates centred around the problem of how to establish filters that held back the cholera agent and its hosts while allowing others to move freely. These debates resonate with the reactions to the coronavirus pandemic in several ways, including the reliance on experts at a time of scientific uncertainty, international organizations mirroring (and weakened by) political hierarchies and power structures, and the role of new means of transport and communication in both causing and potentially solving a global health crisis.

What was most striking for contemporaries in the second half of the nineteenth century was the idea that cholera could hit anyone anywhere. The disease came to embody the wider fears of proximity and speed that the transport and communication revolution of the nineteenth century engendered, undermining the feelings of security and superiority of the emerging global bourgeoisie. ${ }^{4}$ For many Europeans, epidemics had their place either in the past (echoing the experience of the Black Death in Europe) or in other, less 'civilized' regions of the world. In the correct order of things, there should be a spatial or temporal distance between themselves and epidemic diseases. In connection with changes related to industrialization, trade, and colonial expansion, however, the fear of global contagion had returned to their doorstep. Cholera outbreaks made it clear that new means of transportation had not only connected faraway spaces, but also linked humans in new and potentially dangerous ways, transforming cholera from a localizable disease to a global threat. What happened to the population of one part of the globe was now a matter of life and death in others.

Despite this widely shared sentiment of a connected humanity, pandemics bring out differences rather than acting as great levellers. In the case of cholera, such differences could play out on various levels. As cholera was and is directly associated with living conditions, it can serve as a barometer of global social inequalities. ${ }^{5}$ But pandemics also expose other differences, for instance in the realm of politics or regarding the public role of science. The responses to nineteenth-century cholera reveal the imperial hierarchies built into the international system from the outset, as well as the discrimination caused by implementing international health measures. ${ }^{6}$ Just as the World Health Organization (WHO) in 2020 mirrors existing power relations, rifts, and conflicts, the international sanitary conferences of the second half of the nineteenth century were not solely concerned with cooperation in the light of a common problem, but with the preservation of certain privileges despite a global health crisis.

To investigate these inequalities and hierarchies and how they related to the dilemma of openness and closure in the time of cholera, this article first provides an overview of the major cholera epidemics since the early nineteenth century, interweaving them with three key historiographical strands, namely social histories, imperial histories, and histories of science. It then analyses the

\footnotetext{
${ }^{3}$ Geoffrey Alderman, 'The Victorian Transport Revolution', Historical Journal 14, no. 3 (1971): 635-44; Philip Sidney Bagwell, The Transport Revolution from 1770 (London: Barnes \& Noble, 1974).

${ }^{4}$ See S. L. Kotar and J. E. Gessler, Cholera: A Worldwide History (Jefferson, NC: McFarland \& Company, 2014), 45; Paul S. B. Jackson, 'Fearing Future Epidemics: The Cholera Crisis of 1892', Cultural Geographies 20, no. 2 (2012): 43-65. For the global bourgeoisie, see David Motadel, Jürgen Osterhammel, and Christof Dejung, eds., The Global Bourgeoisie: The Rise of the Middle Classes in the Age of Empire (Princeton: Princeton University Press, 2019).

${ }^{5}$ Christian Olaf Christiansen and Steven L. B. Jensen, eds., Histories of Global Inequality: New Perspectives (Cham: Springer, 2019); Walter Scheidel, The Great Leveler: Violence and the History of Inequality from the Stone Age to the Twenty-First Century (Princeton: Princeton University Press, 2017).

${ }^{6}$ For imperial hierarchies and the 'politics of difference', see Jane Burbank and Frederick Cooper, Empires in World History: Power and the Politics of Difference (Princeton: Princeton University Press, 2011).
} 
international measures taken against the cholera epidemics by visiting the boardrooms of the international sanitary conferences, the quarantine stations of the Red Sea administered by international boards and councils, and the steamships trying to pass unhindered between Asia and Europe.

\section{Cholera historiographies: social inequalities, imperial hierarchies, and scientific uncertainties}

Cholera is an infectious disease caused by a microbe mainly found in faeces-contaminated water. If that water is consumed and a person catches cholera, the disease manifests with sudden diarrhoea and stomach cramps, leading to the quick deterioration of the affected person's health. Left untreated, it causes massive dehydration that can kill victims within less than a day. Today, the disease can be remedied with antibiotics and can be prevented by an oral vaccine and, more generally, by access to clean water and healthy living conditions. ${ }^{7}$

While the precise numbers and trajectories remain disputed, cholera is commonly assumed to have spread from India, where it had been endemic, for the first time in 1817, followed by several distinct epidemics along increasingly busy trade routes, bringing the disease to numerous world regions. ${ }^{8}$ The first epidemic (1817-24) carried cholera beyond India to China and Indonesia. The second epidemic (1826-37) struck Europe and North America with severity. A third epidemic (1846-60) travelled via Russia to Great Britain, France, and the USA. A fourth epidemic (1863-75) was linked with the pilgrimage to Mecca and claimed many victims in Asia, the Middle East, and North Africa, spreading to subSaharan Africa as well as to Europe. The fifth wave of the nineteenth century (1881-96) rekindled the disease in Europe, Asia, and South America. The new epidemiological knowledge of the late nineteenth century did not lead to an eradication of cholera. But, as a result of more fervent public health campaigns and more efficient treatment based on bacteriological knowledge, there were no notable cholera outbreaks in Europe in the twentieth century. The sixth epidemic (1899-1923) hit a Russia ravaged by revolution and war. The seventh epidemic started in Indonesia in 1961 and continues to this day.

Regardless of its persistence in many world regions, cholera has been called the 'signal disease of the nineteenth century. ${ }^{9}$ As it circled the globe, and despite its clear link to imperial and commercial enterprises, it came to be seen as an urban disease par excellence, connected with the unsanitary living conditions of workers and sailors in growing towns and capitals. ${ }^{10}$ Port cities and metropoles such as Hamburg, New York, London, and Naples were struck particularly violently, but cholera also travelled via land routes, reaching Moscow and Berlin. Even before its causes could be scientifically described, it was linked to poor sanitation and to overcrowding in houses and on ships. Cholera has therefore served as a prism to understand social inequalities. ${ }^{11}$ It has provided an ideal frame for portraits of nineteenthcentury port cities such as Hamburg and Naples that connect medical and social histories. ${ }^{12}$ Authors such

\footnotetext{
${ }^{7}$ For overviews, see Christopher Hamlin, Cholera: The Biography (Oxford: Oxford University Press, 2009); Kotar and Gessler, Cholera; Mark Harrison, 'Disease and World History from 1750', in The Cambridge World History, Volume 7: Production, Destruction and Connection, 1750-Present, Part 1: Structures, Spaces, and Boundary Making, ed. J. R. McNeill and Kenneth Pomeranz (Cambridge: Cambridge University Press, 2015), 237-57.

${ }^{8}$ Even the origins in India are debated: see Srabani Sen, 'Indian Cholera: A Myth', Indian Journal of the History of Science 47, no. 3 (2012): 345-74.

${ }^{9}$ Hamlin, Cholera, 4.

${ }^{10}$ Amanda J. Thomas, Cholera: The Victorian Plague (Barnsley: Pen \& Sword History, 2015).

${ }^{11}$ Asa Briggs, 'Cholera and Society in the Nineteenth Century', Past \& Present 19, no. 1 (1961): 76-96; Roderick E. McGrew, 'The First Cholera Epidemic and Social History', Bulletin of the History of Medicine 34 (1960): 61-73.

${ }^{12}$ Richard J. Evans, Death in Hamburg: Society and Politics in the Cholera Years 1830-1910 (London: Penguin, 1990); Frank M. Snowden, Naples in the Time of Cholera, 1884-1911 (Cambridge: Cambridge University Press, 1995); François Delaporte, Disease and Civilization: The Cholera in Paris, 1832 (Cambridge, MA: MIT Press, 1989); Barbara Dettke, Die asiatische Hydra. Die Cholera von 1830/31 in Berlin und den preußischen Provinzen Posen, Preußen und Schlesien (Berlin: Walter de Gruyter, 2013); Michael Durey, The Return of the Plague: British Society and the Cholera, 1831-2 (Dublin: Gill and Macmillan, 1979); Roderick E. McGrew, Russia and the Cholera: 1823-1832 (Madison: University of Wisconsin Press, 1965).
} 
as Richard J. Evans have written rich urban histories to show how the disease spotlighted the downside of industrialization. Evans has also pointed to the protest movements and 'cholera riots' which occurred in many cities in reaction to quarantine and other governmental measures to counter the disease. ${ }^{13}$

Since these earlier social history interventions, studies of cholera have expanded well beyond Europe. This is appropriate, as cholera disproportionately affected regions outside the West and continues to reveal global as well as social inequalities. Densely researched cholera histories have appeared for a wide variety of locations, such as India the Ottoman empire, taking specificities of context and period into account rather than painting cholera's picture with a broad brush. ${ }^{14}$ Uncovering the many meanings of the disease, such regional research has exposed divergent chronologies and has thus added to our understandings of global diversity and differentiation. ${ }^{15}$ Mark Harrison has shown how the reactions and protests in India between 1817 and 1821 differed from those connected to later nineteenth-century epidemics and that, unlike others, this early epidemic 'did little to exacerbate tensions between rulers and the ruled'. ${ }^{16}$ In this period, cholera was seen as a natural disaster with little that could be done about it, an attitude that only changed in the 1830s. Some of this research has demonstrated just how difficult it can be to excavate local experiences and perceptions of the disease. ${ }^{17}$ Other studies have significantly shifted conventional geographies, for instance by focusing on relations between Iran and the Ottoman empire. ${ }^{18}$

In order to fully understand the global implications of nineteenth-century cholera, it is important to expand beyond local and national perspectives and to link the disease to broader fears of global contagion. The epidemics coincided with the perception of shrinking time and space in the age of colonial expansion. At the same time, they highlighted racial prejudices around the origins of disease: a hygiene report presented to the international sanitary conference of 1866 stated that 'The Asiatic cholera, profiting, like man, from the modern discoveries, makes its incursions much easier than fifty years ago, and it spreads afar with all the rapidity of steamships and railway.' ${ }^{19}$ Beyond industrialization and urbanization, the cholera epidemics of the nineteenth century were

\footnotetext{
${ }^{13}$ Richard J. Evans, 'Epidemics and Revolutions: Cholera in Nineteenth-Century Europe', Past \& Present 120, no. 1 (1988): 123-46; Richard S. Ross III, Contagion in Prussia, 1831: The Cholera Epidemic and the Threat of the Polish Uprising (Jefferson, NC: McFarland, 2015); S. K. Cohn Jr, 'Cholera Revolts: A Class Struggle We May Not Like', Social History 42, no. 2 (2017): 162-80.

${ }^{14}$ David Arnold, Colonizing the Body: State Medicine and Epidemic Disease in Nineteenth-Century India (Berkeley: University of California Press, 1993); Mark Harrison, Public Health in British India: Anglo-Indian Preventive Medicine 1859-1914 (Cambridge: Cambridge University Press, 1994); Mark Harrison, 'A Question of Locality: The Identity of Cholera in British India, 1860-1890', in Warm Climates and Western Medicine: The Emergence of Tropical Medicine, 1500-1900, ed. David Arnold (Leiden: Brill, 1996): 133-59; Michael Zeheter, Epidemics, Empire, and Environments: Cholera in Madras and Quebec City, 1818-1910 (Pittsburgh: University of Pittsburgh Press, 2015); Mark Harrison, 'The Great Shift: Cholera Theory and Sanitary Policy in British India, 1867-1879', in Society, Medicine and Politics in Colonial India, ed. Biswamoy Pati and Mark Harrison (London: Routledge India, 2018); Isacar A. Bolaños, 'The Ottomans during the Global Crises of Cholera and Plague: The View from Iraq and the Gulf, International Journal of Middle East Studies 51, no. 4 (November 2019): 603-20; Birsen Bulmuş, Plague, Quarantines and Geopolitics in the Ottoman Empire (Edinburgh: Edinburgh University Press, 2012); Myron J. Echenberg, Africa in the Time of Cholera: A History of Pandemics from 1817 to the Present (Cambridge: Cambridge University Press, 2011); Robert Peckham, 'Symptoms of Empire: Cholera in Southeast Asia, 18201850', in The Routledge History of Disease, ed. Mark Jackson (London: Routledge, 2016), 183-201.

${ }^{15}$ See Nile Green, 'The Waves of Heterotopia: Toward a Vernacular Intellectual History of the Indian Ocean', American Historical Review 123, no. 3 (2018): 846.

${ }^{16}$ Mark Harrison, 'A Dreadful Scourge: Cholera in Early Nineteenth-Century India', Modern Asian Studies 54, no. 2 (2020): 502-53.

${ }^{17}$ Peter A. Coclanis, 'Contagion: Thinking about Cholera in Nineteenth-Century Burma', Southeast Review of Asian Studies 30 (2008): 166-76.

${ }^{18}$ Sabri Ateş, 'Bones of Contention: Corpse Traffic and Ottoman-Iranian Rivalry in Nineteenth-Century Iraq', Comparative Studies of South Asia, Africa and the Middle East 30, no. 3 (2010): 512-32; Amir A. Afkhami, A Modern Contagion: Imperialism and Public Health in Iran's Age of Cholera (Baltimore: Johns Hopkins University Press, 2019).

${ }^{19}$ Procès-verbaux de la Conférence sanitaire internationale ouverte à Constantinople le 13 février 1866 (Constantinople, 1866), 'Annexe au Procès-verbal de la 24 Séance, Rapport sur les mesures d'hygiène à prendre contre le cholera Asiatique', 4, quoted in Valeska Huber, 'The Unification of the Globe by Disease? The International Sanitary Conferences on Cholera, 1851-1894', Historical Journal 49, no. 2 (2006): 455.
} 
hence clearly related to the increase in transport and communications that girdled the globe. In this context, contagion came to carry rich metaphorical meaning, connecting disease and politics in intricate ways. $^{20}$

Contagion has consequently provided a lens for more wide-ranging histories of the imperial age and the related tension between freedom of movement and control. ${ }^{21}$ Alison Bashford and Robert Peckham have demonstrated how epidemics underline the vulnerability of empires, which constantly feared their disintegration even as they were expanding. ${ }^{22}$ In the face of this sense of threat, the routine measures to stop an epidemic ran counter to the political and commercial interests of European empires, which were thriving on the new means of transport and communication.

This was particularly true of the quarantine system of the Mediterranean, which had initially been established to stop the plague. ${ }^{23}$ Subsequently, other diseases such as smallpox and yellow fever were added to the list. ${ }^{24}$ When cholera broke out on board or when a ship had left a diseased port, it had to undergo quarantine periods of varying length before being allowed to land. ${ }^{25}$ Quarantine was not only expensive and time-consuming for the individual traveller, but measures seemed arbitrary and lacking a scientific basis, for instance when it came to questions of disease propagation via objects or touch. In the early 1850s, an inmate described the quarantine system in Malta as 'the Moloch of Quarantine, an abuse which, having teased the travelling world in the East for the last three hundred and sixty-five years, should no longer be permitted to remain as a blot upon the institutions of any nation pretending to be removed even one step beyond barbarism'. ${ }^{26}$ Not only was the Mediterranean quarantine system of the 1830s largely unsuccessful in halting the disease, ${ }^{27}$ but it was also a hindrance to more strongly integrated systems of travel and trade, in which being on time increasingly mattered. ${ }^{28}$

Contemporaries therefore campaigned for science to give answers that would allow for more effective and less cumbersome health measures, exposing how tightly political agendas and scientific advice were intertwined. A huge number of pamphlets appeared around cholera causation and its best treatment. Nation-states offered rewards and prizes for scientific discoveries or a cure. $^{29}$ These debates culminated in a conflict between contagionists, those who pushed bacteriological research as the solution, and anticontagionists, who argued that local conditions such as

\footnotetext{
${ }^{20}$ Christoph Gradmann, 'Invisible Enemies: Bacteriology and the Language of Politics in Imperial Germany', Science in Context 13, no. 1 (2000), 9-30.

${ }^{21}$ Mark Harrison, Contagion: How Commerce Has Spread Disease (New Haven: Yale University Press, 2012). More generally on mobility in the age of empire, see Valeska Huber, Channelling Mobilities: Migration and Globalisation in the Suez Canal Region and Beyond, 1869-1914 (Cambridge: Cambridge University Press, 2013).

${ }^{22}$ Alison Bashford, Imperial Hygiene: A Critical History of Colonialism, Nationalism and Public Health (New York: Springer, 2003), Robert Peckham, ed., Empires of Panic: Epidemics and Colonial Anxieties (Hong Kong: Hong Kong University Press, 2015); Alison Bashford “'The Age of Universal Contagion”: History, Disease and Globalization', in Medicine at the Border: Disease, Globalization and Security, 1850 to the Present, ed. Alison Bashford (Basingstoke: Palgrave Macmillan, 2006), 1-18; Peter Baldwin, Contagion and the State in Europe, 1830-1930 (Cambridge: Cambridge University Press, 1999).

${ }^{23}$ Alison Bashford, ed., Quarantine: Local and Global Histories (London: Macmillan, 2016); Alex Chase-Levenson, The Yellow Flag: Quarantine and the British Mediterranean World, 1780-1860 (Cambridge: Cambridge University Press 2020).

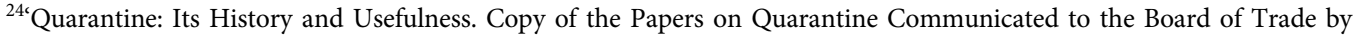
Quarantine Committee of the National Association for the Promotion of Social Science', Literary Gazette 176, no. 2336, 9 November 1861.

${ }^{25}$ Bronwen E. J. Goodyer, ‘An Assistant Ship Surgeon's Account of Cholera at Sea', Journal of Public Health 30, no. 3 (2008): 332-38.

${ }^{26}$ 'Recollections by a Quarantine Detenu', Sharpe’s London Magazine, July 1852, 1-12.

${ }^{27}$ Benoît Pouget, 'Quarantine, Cholera, and International Health Spaces: Reflections on Nineteenth-Century European Sanitary Regulations in the Time of the SARS-CoV-2', Centaurus 62, no. 2 (2020): 302-10.

${ }^{28}$ Vanessa Ogle, The Global Transformation of Time 1870-1950 (Cambridge MA: Harvard University Press, 2015); On Barak, On Time: Technology and Temporality in Modern Egypt (Berkeley: University of California Press, 2013).

${ }^{29}$ Kotar and Gessler, Cholera, 36.
} 
miasmata caused the disease. ${ }^{30}$ In line with its political and commercial interests, Britain pressed heavily for an anticontagionist agenda, going so far as to preventing bacteriological research in India altogether. However, in the context of the broader successes of bacteriology, Robert Koch managed to isolate the vibrio cholerae microbe during his expedition to Egypt in 1882 and subsequently large parts of the scientific community became convinced of the bacteriological causation of cholera. ${ }^{31}$

While earlier histories of science have focused on actors such as Robert Koch as 'the heroes of disease prevention', ${ }^{32}$ more recent scholarship has emphasized the darker side of medical doctors' work, particularly their involvement in the colonies. ${ }^{33}$ Histories of science have moved from great men and their success stories to more complex pictures marked by competition and contingency, and analyses of professionalization and standardization processes have replaced simple narratives of discovery. ${ }^{34}$ A closer investigation of Koch's research in Egypt shows how much not only the broader scientific and political context mattered, but also local conditions and collaborations. As the cholera epidemics were under way, science happened on the go and was hit and miss, leading in turn to the implementation of measures such as isolation, sterilization, and disinfection before they had been fully tested. Nineteenth-century cholera is therefore a perfect case to examine the role of science and its political entanglements in the context of an ongoing health crisis. Communication assumed a double meaning in this context: not only was the bone of contention whether cholera was a communicable disease in the first place, but science communication moved to the forefront as medical experts took on a new role in the public sphere.

As this overview indicates, there are limits to cholera historiographies if they remain cloistered in distinct subfields. Histories of pandemics can show poignantly how science is connected with imperial politics, and how imperial hierarchies fostered social inequalities, which in turn led to susceptibility of disease outbreaks in certain neighbourhoods or regions. The following short visits to three spaces where social inequalities, imperial hierarchies, and scientific conflicts and uncertainties became particularly apparent - notably the conference boardroom, the quarantine station, and the steamship in transit - interweave the larger-scale questions with the value of a microhistorical method. Global microhistory has developed as a particularly promising approach in global history. ${ }^{35}$ Yet, with its emphasis on individual biographies, it is less often employed in relation to global histories of disease, and nor has it found wide-reaching application to illuminate and differentiate histories of internationalism. ${ }^{36}$ Using cholera as a stepping stone, the

\footnotetext{
${ }^{30}$ Erwin Ackerknecht, 'Anticontagionism between 1821 and 1867', Bulletin of the History of Medicine 22 (1948): 562-93; Michael Worboys, Spreading Germs: Disease Theories and Medical Practice in Britain, 1865-1900 (Cambridge: Cambridge University Press, 2000).

${ }^{31}$ Christoph Gradmann, 'Das reisende Labor: Robert Koch erforscht die Cholera 1883/84', Medizinhistorisches Journal 38, no. 1 (2003): 35-56; Steve M. Blevins and Michael S. Bronze, 'Robert Koch and the "Golden Age" of Bacteriology', International Journal of Infectious Diseases 14, no. 9 (2010): 744-51.

${ }^{32}$ Rebecca Whyte, 'Cholera and Venereal Disease', British Library Newspapers (Detroit: Gale, 2007), https://www.gale.com/ intl/essays/rebecca-whyte-cholera-venereal-disease.

${ }^{33}$ Aro Velmet, Pasteur's Empire: Bacteriology and Politics in France, Its Colonies, and the World (Oxford: Oxford University Press, 2019).

${ }^{34}$ Owen Whooley, Knowledge in the Time of Cholera: The Struggle over American Medicine in the Nineteenth Century (Chicago: University of Chicago Press, 2013); Mariko Ogawa, 'Uneasy Bedfellows: Science and Politics in the Refutation of Koch's Bacterial theory of Cholera', Bulletin of the History of Medicine 74, no. 4 (2000): 671-707; William Johnston, 'The Shifting Epistemological Foundations of Cholera Control in Japan (1822-1900)', Extrême-Orient Extrême-Occident 37 (2014): 171-96.

${ }^{35}$ See, most recently, John-Paul Ghobrial, ed., Global History and Microhistory, Past \& Present supplement 14 (2019).

${ }^{36}$ From an ever growing body of literature, see Akira Iriye, Cultural Internationalism and World Order (Baltimore: Johns Hopkins University Press, 1997); Martin H. Geyer and Johannes Paulmann, The Mechanics of Internationalism: Culture, Society, and Politics from the 1840s to the First World War (Oxford: Oxford University Press, 2001); Mark Mazower, Governing the World: The History of an Idea (London: Penguin, 2012); Glenda Sluga, Internationalism in the Age of Nationalism (Philadelphia: University of Pennsylvania Press, 2013); Susan Pedersen, The Guardians: The League of Nations and the Crisis of Empire (Oxford: Oxford University Press, 2015); Glenda Sluga and Patricia Clavin, eds., Internationalisms: A Twentieth-Century History (Cambridge: Cambridge University Press, 2017).
} 
following vignettes explore the potential that microhistory holds for future histories of internationalism.

\section{Microhistories of internationalism: the boardroom, the quarantine station, and the steamship}

From 1851 onwards, a number of international sanitary conferences were convened in Paris, Constantinople, Vienna, Rome, Venice, and Dresden to deal with the problem of cholera dissemination, signalling the start of international cooperation in the field of public health. ${ }^{37}$ Inequality not only played a role on a social level, with the poorest most affected by a disease spread by dirty water and deficient sanitary conditions. It also extended into the boardrooms of international conferences, where the logics of imperial expansion and competition were replicated. While many participants might have agreed that cholera concerned all of humanity, the proposed solutions did not conceive of an equal world where uniform concern was shown for 'the whole human race', nor were the debates conducted in such a manner. Even if the conferences were international in name, the solutions they proposed were not of equal benefit to all. Instead, debates revolved around how traditional barriers against epidemics could be lowered while at the same time keeping Europe secure from the importation of the disease. The goal of the conferences was therefore not to eradicate cholera but to keep it from spreading while at the same time safeguarding trade and imperial traffic.

Despite the overarching rhetoric of universality and brotherhood, the lengthy debates of the early international sanitary conferences illustrate the difficulties in reaching agreement - for instance when it came to questions of who should pay for certain measures. Scientists and diplomats, European delegates, and the few participants from Middle Eastern and Asian countries struggled to find a common language, while conflicts and power-brokering were barely disguised. Whereas scientists carried on their own battles regarding disease causation, scientists and diplomats often had problems to even understand each other. The first conference was much less standardized than later conferences, lasted almost six months, and saw scientists hold lengthy speeches on different theories of disease causation. At the 1859 conference, only diplomats were invited, in order to avoid long scientific debates. At the subsequent conferences of Constantinople (1866) and Vienna (1885), and in line with increasing political reliance on science and expertise, individual doctors such as the French delegates Antoine Fauvel and Adrien Proust became more vocal, proposing new scientific measures that would lower barriers, which was of course very much in the interest of many diplomats attending the meetings. As the conferences moved into the 1890s, their proceedings became more professional and institutionally mature.

The conference boardrooms were not only a battleground among scientists regarding disease causation, and between scientists and diplomats about the most effective measures to be taken. They also served as arenas for competing European nations and empires to display their strength providing a forum for France, Germany, and Britain to exercise their rivalry. ${ }^{38}$ At the 1885 conference of Vienna, France and Germany could barely hide their disagreement in the aftermath of the Franco-Prussian War of the early 1870s. At the same time, the Germans and French were united in attempts to counterbalance British power and to 'force England to reckon with

\footnotetext{
${ }^{37}$ For a more detailed analysis of the conferences, see Huber, 'Unification of the Globe by Disease?'; Norman Howard-Jones, The Scientific Background of the International Sanitary Conferences, 1851-1938 (Geneva: World Health Organization, 1975); Mark Harrison, 'Disease, Diplomacy and International Commerce: The Origins of International Sanitary Regulation in the Nineteenth Century', Journal of Global History 1, no. 2 (2006): 197-217; Sylvia Chiffoleau, Genèse de la santé publique internationale. De la peste d'Orient à l'OMS (Rennes: Presses universitaires de Rennes, 2019).

${ }^{38}$ Francisco Javier Martínez, 'International or French? The Early International Sanitary Conferences and France's Struggle for Hegemony in the Mid-Nineteenth Century Mediterranean', French History 30, no. 1 (2016): 77-98.
} 
Europe a little more'. ${ }^{39}$ Yet Britain withdrew from the 1885 debates and no international agreement on cholera would be reached until 1892. Despite much flowery rhetoric, international conferences were not about international cooperation but about displaying power in order to push through an agenda or to block one altogether.

If there were clear rifts between European powers, the strongest hierarchies in the boardroom were displayed between Europeans and non-Europeans. The conferences were not only mainly staffed by Europeans, they also carried an explicitly European agenda. This emphasis on Europe and Europeans was particularly striking, as the fight against the cholera microbe was not intended to take place within Europe but rather at its margins, particularly in the Ottoman empire, where those entering the Mediterranean were supposed to be thoroughly checked. In part because Britain had blocked meaningful intervention in India, many measures proposed at the conferences were about preventing the spread of infections from the territories of the Ottoman empire to the European continent. The institutions and measures discussed at the conferences represented substantial external interventions within the territory of the Ottoman empire, as the eastern Mediterranean and the Red Sea were to serve as a buffer zone between the Asian origin of the disease and Europe. The proposals extended the capitulations which already granted Western powers extensive rights in the Ottoman territories. ${ }^{40}$ The Ottoman Health Council in charge of many of the proposed measures would be predominantly staffed with foreign members, while the Ottoman empire and Egypt were largely to pay for a European sanitary bulwark erected on Ottoman territories, much in line with the growing dependency of these territories on Europe. ${ }^{41}$

Despite their financial commitments and the central role that their territories were to play in the control of the cholera epidemics, Ottoman, Egyptian, and Persian delegates were hardly considered peers at the conferences. One of them was the diplomat and publicist Mirza Malkom Khan, who attended the conference in Constantinople and would later become a well-known constitutional reformer in Iran. ${ }^{42}$ At the 1866 conference he countered the condescending treatment with subtle irony: 'If I have difficulties grasping the sense and the connections between your statements, that should not astonish you: I come from the centre of Asia, and I would like to hope that this origin would suffice to make me at a European conference the object of leniency which would moreover only heighten your superiority. ${ }^{33}$ In more informal occasions, other participants did not disguise their fury. The British delegate at the 1894 conference met with his Ottoman counterpart and reported: 'After remaining silent through the whole Conference, he said that he had been boiling internally throughout its progress at the manner in which it pretended to legislate on internal matters in Turkey ("qui est, que diable, un Empire independent!")'. ${ }^{44}$ Discussions in the boardroom thus mirrored imperial hierarchies outside the field of health. Even if, in an age of increased and increasingly rapid communications, no epidemic disease could be fought by any one power

\footnotetext{
${ }^{39}$ Nationalzeitung, 20 May 1885, R/901/220399, Bundesarchiv, Berlin, quoted in Huber, 'Unification of the Globe by Disease?', 466.

${ }^{40}$ Nermin Ersoy, Yuksel Gungor, and Aslihan Akpinar, 'International Sanitary Conferences from the Ottoman Perspective (1851-1938)', Hygiea Internationalis: An Interdisciplinary Journal for the History of Public Health 10, no. 1 (2011): 53-79; Obijilofor Aginam, 'The Nineteenth-Century Colonial Fingerprints on Public Health Diplomacy: A Postcolonial View', Law, Social Justice \& Global Development Journal 1 (2003), https://warwick.ac.uk/fac/soc/law/elj/lgd/2003_1/aginam/.

${ }^{41}$ Alison Bashford “"The Age of Universal Contagion”: History, Disease and Globalization', in Medicine at the Border, ed. Bashford, 7.

${ }^{42}$ Hamid Algar, Mirza Malkum Khan: A Biographical Study in Iranian Modernism (Berkeley: University of California Press, 1973); Hassan Bashir, 'Qanun and the Modernisation of Political Thought in Iran', Global Media Journal 8, no. 14 (2009): $1-39$.

${ }^{43}$ Printed addition to an interrupted speech by Mirza Malkom Khan, p. 1, Foreign Office 78/2006, The National Archives, London (hereafter cited as TNA), quoted in Huber, 'Unification of the Globe by Disease?', 463.

${ }^{44} \mathrm{Mr}$ Phipps to Foreign Office, Paris, 28 March 1894, Ministry of Health 19/238, TNA, quoted in Huber, 'Unification of the Globe by Disease?', 469.
} 
alone, this did not induce a discussion among equal partners. The conferences were international in name but barely hid their imperial agenda.

If distinctions and hierarchies were central to the proceedings of the conferences, they also had a bearing on the implementation of the schemes they proposed. Within the boardrooms, European powers may have 'held the reins of an international health system which was based on a subtle dialectical relationship between the construction of an international public health space and the affirmation of state sovereignty'. ${ }^{45}$ In practice, however, the Ottoman state was not merely a victim of European intervention, but became a critical driver in implementing international policies and defending its territories against cholera from India. ${ }^{46}$ What is more, as health and hygiene measures were put into operation, they mattered to empires and their commercial enterprises, but also and most fundamentally to individual lives in transit. Debates in boardrooms in Paris, Vienna, or Istanbul could mean intervention at the level of individuals, by surveying them, making them change their behaviour, detaining them, saving them from disease, or letting them die - all in the name of international health. It is therefore vital for histories of internationalism to move from the boardrooms of international conferences to the application of their proposals.

The international sanitary conferences recommended several ways of solving the dilemma of simultaneous openness and closure, such as the creation of modern quarantine stations as 'sorting houses' and procedures of contactless travel. ${ }^{47}$ The simplest scheme to keep transport running smoothly in the time of cholera was to differentiate between groups of travellers, splitting mobile people into risk and non-risk groups, with quarantine and isolation applied to some and not to all. At the sanitary conferences, such differentiation was codified in new ways. Warships should be allowed to pass freely and were exempt from international regulation, ${ }^{48}$ whereas other groups were always treated as suspicious, among them 'gypsies', itinerant people, and cross-border migrants. ${ }^{49}$ Identifying supposed risk groups and potential disease spreaders was therefore a key strategy in the emerging international health system along imperial lines, where military and commercial movements were to remain free from stigma, separating them from mass pilgrimage and other subaltern mobilities.

In the eastern Mediterranean and Red Sea, British and French imperial officers branded Mecca pilgrims as disease carriers par excellence, connecting them to the sanitary crisis but also to the threats of pan-Islam and anti-colonial activism..$^{50}$ During the debates around cholera prevention, the Mecca pilgrimage moved to centre stage from the 1860s onwards, after around 15,000 pilgrims died of cholera in $1865 .^{51}$ This was linked to the faster transit of pilgrims, who were now travelling

\footnotetext{
${ }^{45}$ Pouget, 'Quarantine, Cholera, and International Health Spaces', 307.

${ }^{46}$ See Michael Christopher Low, Imperial Mecca: Ottoman Arabia and the Indian Ocean Hajj (New York: Columbia University Press, 2020), 117-66: 'Microbial Mecca and the Global Crisis of Cholera'.

${ }^{47}$ Kris Anderson, Subversive Seas: Anticolonial Networks across the Twentieth-Century Dutch Empire (Cambridge: Cambridge University Press, 2019), 152.

${ }^{48}$ Ministère des Affaires Etrangères, Protocoles de la Conférence sanitaire internationale ouverte à Paris le 9 avril 1859 (Paris, 1859), annex protocol no. 24, 'Rapport sur la patente des bâtiments de guerre', 9-10.

${ }^{49}$ International Sanitary Convention Dresden, British Parliamentary Papers (1893-4), 109: 161; 'Fragebogen für eine internationale Sanitätskonferenz zur Abwehr der Cholera', Die Abhaltung internationaler Cholera-Conferenzen (4. Februar 1893 bis 31 Oktober 1894), Rep. 77 Tit. 247 Nr. 64, Geheimes Staatsarchiv, Berlin.

${ }^{50}$ William Roff, 'Sanitation and Security: The Imperial Powers and the Nineteenth-Century Hajj', Arabian Studies 4 (1982): 143-60; Michael Christopher Low, 'Empire and the Hajj: Pilgrims, Plagues and Pan-Islam under British Surveillance, 1865-1908', International Journal of Middle East Studies 40, no. 2 (2008): 269-90; John Slight, The British Empire and the Hajj (Cambridge, MA: Harvard University Press, 2015); Ulrike Freitag, A History of Jeddah: The Gate to Mecca in the Nineteenth and Twentieth Centuries (Cambridge: Cambridge University Press, 2020), esp. 260-7.

${ }^{51}$ Michael Christopher Low, 'Ottoman Infrastructures of the Saudi Hydro-State: The Technopolitics of Pilgrimage and Potable Water in the Hijaz', Comparative Studies in Society and History 57, no. 4 (2015): 944. See also Valeska Huber, 'International Bodies: The Pilgrimage to Mecca and International Health Regulations', in The Hajj: Pilgrimage in Islam, ed. Eric Tagliacozzo and Shawkat Toorawa (Cambridge: Cambridge University Press, 2015), 175-95; Saurab Mishra, Pilgrimage, Politics, and Pestilence: The Haj from the Indian Subcontinent, 1860-1920 (New Delhi: Oxford University Press, 2011).
} 
on steamships rather than caravans and sailing boats, which, owing to the length of the journey, had served as 'natural quarantine'. Despite the general criticism of quarantine voiced at the international sanitary conferences and beyond, and despite the protest of Muslim delegates, prescribing a mandatory fifteen-day quarantine for Mecca pilgrims did not pose a problem in the eyes of many Western delegates. As a result, stringent control measures targeting Mecca pilgrims were put into place. Consequently, international, imperial, and national boards and councils established a quarantine archipelago, among them al-Tur and Kamaran on both sides of the Red Sea, Anadolu Kavagi, Sinop, and Trabzon in the Black Sea, and Izmir in the Mediterranean. ${ }^{52}$

The quarantine station of al-Tur in the Gulf of Suez was established in 1877 under the aegis of the Sanitary Maritime and Quarantine Board of Egypt and was initially designed to hold up to 6,000 pilgrims in isolated sections in which pilgrims had to remain for at least fifteen days after the last case of cholera had emerged. After coming ashore, the pilgrims had to strip naked with their belongings and clothes disinfected, were handed a sterilized shirt, and were obliged to take a shower or a bath before being sorted into different categories of healthy and ill. During cholera epidemics, all the pilgrims then had to continue by train into the militarily guarded sections of the station, which were surrounded by three-metre-high wire fences and separated by at least one empty section in between. Each section contained one hundred tents, to accommodate six pilgrims respectively, and was catered for by a 'café, where the pilgrims may buy their food and a few little luxuries', as Armand Ruffer, president of the Quarantine Board, euphemistically stated. ${ }^{53}$

The British consul general John Long prided himself on the technical equipment and meticulous execution of procedures, the quarantine station being able 'to pass through over 100 pilgrims an hour'. ${ }^{54}$ In his report of 1900 , Ruffer was equally fond of the arrangements in al-Tur, all financed by the Egyptian government and containing modern features of disinfection, a bacteriological laboratory, running water, telephone, and railway: 'With regard to the pilgrimage, the measures are fairly satisfactory, because the pilgrims at Tor are, so to speak, in our power, and because time is of little object, and the disinfecting plant is sufficient. ${ }^{55}$ Such statements demonstrate not only the condescending manner with which pilgrims were treated but also the convenient sacrifice of slowing down those forms of communication which were not deemed essential for running global trade and empire.

Despite the factory-like arrangements, the measures were difficult to execute in practice. Ruffer referred directly to the boardrooms of the 1892 sanitary conference in Venice when he stated:

The regulations appear simple enough, and would indeed be so, were it not that one had to deal with an enormous mass of people arriving by batches of 500 and 1000 at a time. I have been not a little astonished by the ease with which gentlemen sitting comfortably in Venice and elsewhere, order the disinfection of hundreds and thousands of individuals. ${ }^{56}$

\footnotetext{
${ }^{52}$ For Kamaran, see Kris Anderson, Subversive Seas: Anticolonial Networks across the Twentieth-Century Dutch Empire (Cambridge: Cambridge University Press, 2019), 149-55; Gülden Sarıyldız and Oya Dağlar Macar, 'Cholera, Pilgrimage, and International Politics of Sanitation: The Quarantine Station on the Island of Kamaran', in Plague and Contagion in the Islamic Mediterranean, ed. Nükhet Varlık (Leeds: Arc Humanities Press, 2017), 243-74; Nuran Yildirim, 'Les mesures de quarantaine prises pendant les épidémies de cholera et leurs repercussions sur la société ottoman (1831-1918)', in Perilous Modernity: History of Medicine in the Ottoman Empire and the Middle East from the 19th Century Onwards, ed. Anne Marie Moulin and Yesim Isil Ulman (Istanbul: Isis Press, 2010), 119-39; Gülden Sarıyıldız, Al-Hajar al-șihhhi fì al-Hijāz 1865-1914 (Quarantine in the Hejaz 1865-1914) (al-Riyāḍ: Markaz al-Malik Fayșal lil-Buhūth wa-al-Dirāsāt al-Islāmīya, 2001).

${ }^{53}$ Marc Armand Ruffer, 'Measures Taken at Tor and Suez against Ships Coming from the Red Sea and the Far East', Transactions. Epidemiological Society of London 19 (1900): 44.

${ }^{54} J o h n$ G. Long, 'Turkey: The Quarantine Camp at El Tor', Public Health Reports (1896-1970) 17, no. 20 (1902): 1156-9.

${ }^{55}$ Ruffer, 'Measures Taken at Tor and Suez', 44.

${ }^{56}$ Ibid., 26.
} 
Many pilgrims were also trading goods and carried large amounts of luggage which had to disinfected, or were ill with different kinds of diarrhoea, making it 'clearly impossible to examine the faeces of hundreds of people bacterioligically $[$ sic $] .{ }^{57}$ Ruffer was also sceptical regarding the possibility of establishing the appropriate length of supervision scientifically and concluded that 'the only safety is the watching of the pilgrims after their arrival in their homes', reminding us of more recent tracking schemes. ${ }^{58}$

The crowded conditions and rough handling not only made disinfection and bacteriological checks difficult to impossible at al-Tur; they also led to massive discontent among the pilgrims themselves, who complained of unclean and brackish drinking water, the quality of food, the insufficient number of tents, and the sum of money that every pilgrim had to pay for the procedures. In stark contrast to the official accounts cited above, travellers such as the Egyptian pilgrim Mohammad Sadiq were shocked by the public disorder and chaos and the damaged tents. To his horror, Sadiq even discovered a decaying corpse in one of them. ${ }^{59}$ The Persian traveller Mohammad Hosayn Farahani criticized the exorbitant fees but also clarified that the measures could easily be circumvented. ${ }^{60}$ Sultan Jahan Begam from Bhopal, a princely state in India, hoped to escape the regulations altogether because of her 'friendship with and fidelity to the British Government' ${ }^{61}$ At times, uprisings and revolt were imminent in al-Tur, echoing the cholera riots mentioned earlier. In 1877, the Egyptian army had to subdue a revolt of pilgrims against the camp supervisors. ${ }^{62}$ In 1893 , more than 12,000 pilgrims were held in the camp of al-Tur and five other ships were about to arrive when the camp director requested help. ${ }^{63}$ Such incidents show how different levels of authority intersected when facing protest and revolt. These glimpses of pilgrims' experiences, which stand in stark contrast to the official depictions that the international delegates at the conferences consumed, also highlight that it is only through stitching together various archives that we can we arrive at fuller histories of internationalism.

Safe passage for some was to be guaranteed not only through the sorting mechanisms outlined above but also via new types of transit, allowing the large ocean steamships to circulate without hindrance. ${ }^{64}$ Steamships, which after the 1860 s had swiftly replaced sail in transcontinental travel, became connected with specific sociabilities and cultural practices. They were in themselves extremely hierarchical entities, consisting of different classes and a highly ordered crew, that have been likened to empires in microcosm. ${ }^{65}$ The categorization on board followed a similar logic of differentiation to the one spelled out above. While medical checks and quarantine were mostly

\footnotetext{
${ }^{57}$ Ibid., 37.

${ }^{58}$ Ibid., 46.

${ }^{59}$ Quoted in Paul Robertson, 'Death and Disorder in Muhammad Sadiq's Star of the Hajj: Steamships, Quarantine and Their Impact on the Muslim Body', in Saddling the Dogs: Journeys through Egypt and the Near East, ed. Diane Fortenberry and Deborah Manley (Oxford: Oxbow Books, 2009), 1-12.

${ }^{60}$ Mohammad Hosayn Farahani, A Shi'ite Pilgrimage to Mecca 1885-1886: The Safarnameh of Mirza Mohammad Hosayn Farahani (Austin: University of Texas Press, 1990); Michael Wolfe, ed., One Thousand Roads to Mecca: Ten Centuries of Travelers Writing about the Muslim Pilgrimage (New York: Grove Press, 2015); Nile Green, 'The Hajj as Its Own Undoing: Infrastructure and Integration on the Muslim Journey to Mecca', Past \& Present 226 (2015): $193-226$.

${ }^{61}$ Nawab Sultan Jahan Begam, The Story of a Pilgrimage to Hijaz (Calcutta: Thacker, Spink \& Co, 1909), 151.

${ }^{62}$ Slight, British Empire and the Hajj, 80.

${ }^{63}$ Dār al-WathāØiq al-Qawmiyya, Cairo, Majlis al-Wuzarāđ, Niðārat al-Dākhiliyya, 18 18/b, 0075-007537: Conseil sanitaire maritime et quarantenaire d'Egypte, 'Communication faite à la présidence du Conseil par le directeur du campement de Tor, al-Tur, 25 July 1893’, quoted in Huber, Channelling Mobilities, 229.

${ }^{64}$ On steamships in transit, see Martin Dusinberre and Roland Wenzlhuemer, 'Being in Transit', special issue of Journal of Global History 11, no. 2 (2016); Frances Steel, Oceania under Steam: Sea Transport and the Cultures of Colonialism, c. 1870-1914 (Manchester: Manchester University Press, 2011); Douglas R. Burgess, Engines of Empire: Steamships and the Victorian Imagination (Stanford: Stanford University Press, 2016); Mark A. Russell, Steamship Nationalism: Ocean Liners and National Identity in Imperial Germany and the Atlantic World (Abingdon: Routledge, 2020).

${ }^{65}$ Janet J. Ewald, 'Crossers of the Sea: Slaves, Freedmen, and Other Migrants in the Northwestern Indian Ocean, c. 1750-1914’, American Historical Review 105, no. 1 (2000): 81; Huber, Channelling Mobilities, 124-7.
} 
limited to third-class passengers and the crew, first-class passengers could expect to pass without interruption or inconvenience, as numerous letters and travel descriptions illustrate.

The most notable experiment with contactless travel and the attempt to turn quarantine into a mobile device was the passage in quarantine through the Suez Canal. ${ }^{66}$ Provided it followed and documented special health and hygiene regulations and could guarantee non-contact with any harbour or shore in the Suez Canal region, a steamship could navigate the global bottleneck without undergoing quarantine on either side. Yet the Suez Canal passage was just one example of contactless travel, where passengers were required to keep a distance from the places they transited. At the 1893 sanitary conference in Dresden, following the meeting in Venice the previous year, delegates argued that the big advantage of trains and steamships more generally was that they were self-contained capsules that could cross large parts of the world without coming into contact with the regions traversed.

Non-contact over large distances relied on administration, science, and the use of up-to-date information technology. As in the case of pilgrim quarantine stations, the scheme highlights the bureaucratization of sanitation, as well as the improvisations and evasions that such bureaucratization engendered. Many observers agreed that captains would do all in their power to avoid checks as soon as they led to financial losses or discontent among the more privileged travellers. Controlling traffic was therefore to a certain extent fictitious, especially as the scientific measures deemed appropriate were in the process of experimentation rather than being tried and tested.

The example of steamships travelling 'in quarantine' relates to the fundamental question of who could keep their distance while being able to move at the same time. Who had the privilege to shield him- or herself, and who was exposed to the epidemic and slowed down simultaneously? According to the sanitary convention of 1892, free passage through the Suez Canal was tied to intricate screening processes and strict regulations. Only ships carrying a doctor and a disinfecting stove on board qualified for the scheme. ${ }^{67}$ If required - for instance, in the case of cholera infections among crew or passengers - fast-track screening and checks could be performed in Moses' Wells, about 6 miles from Suez, which was considered a 'disinfecting establishment model of its kind'. ${ }^{68}$ It was much smaller than al-Tur, designed to hold fifty passengers at one time. Furthermore, the shores of the canal were strictly guarded by military patrols to ensure that no person or object could debark the ship. The guards and pilots who had to accompany the ship during transit through the canal were supervised in a floating quarantine station in the canal zone upon leaving the vessel. Disembarking stokers and seamen, part of the logistical routine in the Suez Canal region, was another challenge, with seamen discharged in Suez, disinfected at Moses' Wells, and then sent back by train to Port Said, while the consul was kept informed via telegram.

As this procedure indicates, beside administration and disinfection, managing and communicating information was a crucial element of contactless travel. In addition to sending telegrams when disembarking parts of the crew, every ship had to dispatch a telegram upon departure from the Suez Canal region to every port it planned to visit, which in turn could refuse the steamship's landing. Assembling trustworthy statistics on cholera outbreaks had been a priority throughout the nineteenth century to gauge the danger disseminating from a certain ship or passenger. ${ }^{69}$ From the 1880s, information technology took on a new role, as information was to be pooled and disseminated internationally. The 1885 conference proposed an international sanitary agency of notification. At the 1892 conference, the Austrian delegate referred to the telegram as a 'prophylactic

\footnotetext{
${ }^{66}$ For a fuller depiction of the Suez Canal scheme, see Huber, Channelling Mobilities, chap. 7: 'Contagious Mobility and the Filtering of Disease'.

${ }^{67}$ Protocols of the International Sanitary Conference, Venice 1892, Protocol 10, 23 January 1892, 175, World Health Organization Library, Geneva.

${ }^{68}$ Ruffer, 'Measures Taken at Tor and Suez', 38.

${ }^{69}$ By 1830 , cholera reports appeared in British newspapers on a daily basis (Kotar and Gessler, Cholera, 36). See also the reports in the medical publications of the Lancet and the British Medical Journal.
} 
measure' alongside scientific procedures. ${ }^{70}$ The reliance on notification and the circulation of information to convey a sense of security in the face of contagion would expand steadily into the interwar period and beyond. ${ }^{71}$

This glance at the implementation of international sanitary measures enables a double shift in writing histories of internationalism. The first is from the boardrooms of international conferences to the regions where the proposals were put into practice. Over the past decades, historians have moved studies of internationalism from an analysis of final results and agreements to finergrained investigations of international conferences and events. Using a similar optic, it is high time to take the history of sanitary internationalism out of the boardrooms to those localities where the schemes discussed at such meetings were actually carried out.

Secondly, in line with more recent microhistorical research, the cases discussed here transfer the attention from space to individuals and their differentiation. For a long time, global historians have been fascinated by questions of space and scale. Consequently, past analyses of the international sanitary conferences have emphasized spatial arrangements with regard to disease control acting at alleged points of origin, shifting the sanitary border of Europe eastwards, and creating new flexible types of border control, such as checkpoints and buffer zones. Yet the three social settings introduced here help to individualize internationalism, showing how the politics of difference played out on individual bodies and how international regulation and personal lives were interlocked.

\section{Conclusion}

To this day, internationalism and cholera are closely entwined. Considering that the international sanitary conferences established to counter the cholera epidemics were the forerunners of the League of Nations' Health Organization and the WHO, it is a terrible irony that international United Nations peace forces are claimed to have brought cholera back to Haiti after the catastrophic earthquake of 2010. The outbreak and ensuing epidemic not only hit extremely poor and vulnerable communities, but also led to difficult investigations as to the origins of the outbreak and to large-scale demonstrations and political protests, turning these events into a tragic showcase of the entanglements of international hierarchies and individual health. ${ }^{72}$

To illuminate such entanglements in an earlier century, the vignettes presented in this article suggest how to incorporate imperial histories, social histories, and histories of science into broader and more grounded histories of internationalism. Frequently, histories of internationalism focus on institutions, while many histories of empire look at macropolitical and macroeconomic structures, and social histories take local actors and constellations seriously. The study of global pandemics past and present makes clear that only by integrating these approaches can we include social inequalities and political hierarchies, as well as protests and evasions, to arrive at fuller (and at times more troubled) histories of internationalism.

Beyond this methodological intervention, revisiting the international sanitary conferences of the nineteenth century sheds new light on the origins of internationalism and the tension between cooperation and political brokering. As prototypes of internationalism, the conferences did not create a level playing field. Instead they were platforms for staging difference. Britain's withdrawal from the discussions in 1885 and its unwillingness to accept any compromise on its anticontagionist stance into the 1890s carries obvious parallels to the US departure from the WHO in 2020, as it does to the race for a vaccination against the coronavirus and the willingness (or not) to make

\footnotetext{
${ }^{70}$ Protocols of the International Sanitary Conference, Venice 1892, Protocol 6, 1 January 1892, 146.

${ }^{71}$ See Heidi Tworek, 'Communicable Disease: Information, Health and Globalization in the Interwar Period', American Historical Review 124, no. 3 (2019): 813-42; Huber, 'International Bodies', 182-4.

${ }^{72}$ Ralph R. Frerichs, Deadly River Cholera and Cover-Up in Post-Earthquake Haiti (Ithaca: Cornell University Press, 2016).
} 
it available to all. More specifically, the nineteenth-century conferences' agenda was not only to secure health but also to secure an imperial mobility regime under conditions of contagion, even if it meant convenient sacrifices, safeguarding the mobility of some at the expense of that of others.

Through the focus on difference and its relation to freedom of movement, the history of responses to nineteenth-century cholera epidemics demonstrates how we can break open the binary of phases of globalization and deglobalization that have long dominated the thinking about global processes, particularly if they are written from the vanguard of economic history. As other historians have noted, it is high time to go beyond conceptualizations of global history in terms of connections. ${ }^{73}$ Yet simply turning to the opposite and including disconnection and disintegration within the research matrix is not sufficient to fix the problem. For the purpose of amalgamating openness and closure into a single framework, this article has proposed the semantic field of difference, including social inequalities, imperial hierarchies, scientific disagreement, competition, discrimination, and protest. If pandemics lead to fragmentation, they are also global by very definition. Or, to come back to the quote at the beginning of this article, the history of nineteenthcentury cholera exposes how, during a pandemic, all of humanity might be living through the same crisis but under fundamentally different conditions, and how such differences are brought about and reinforced.

Valeska Huber is head of the Emmy Noether Research Group 'Reaching the People: Communication and Global Orders in the Twentieth Century' at the Department of History, Freie Universität Berlin. Her research focuses on migration and mobility, on health and disease control, and on communication in the twentieth century. She is currently writing a book on education for all in the American Century and embarking on a new project on global languages. She is the author of Channelling Mobilities: Migration and Globalisation in the Suez Canal Region and Beyond, 1869-1914 (Cambridge University Press, 2013) and co-editor, with Jürgen Osterhammel, of Global Publics: Their Power and Their Limits 1870-1990 (Oxford University Press, 2020).

\footnotetext{
${ }^{73}$ See, for instance, Jeremy Adelman's contribution, 'What Is Global History Now?', Aeon, 2 March 2017, https://aeon.co/ essays/is-global-history-still-possible-or-has-it-had-its-moment, and the ensuing debate.
}

Cite this article: Huber V. 2020. Pandemics and the politics of difference: rewriting the history of internationalism through nineteenth-century cholera. Journal of Global History 15: 394-407, doi:10.1017/S1740022820000236 